\title{
The Evolution of BRICS in International Political Economy
}

\author{
C.C. Shameem \\ K. Jayaprasad
}

\begin{abstract}
In a highly interdependent and globalized era, the BRICS economic regionalism exhibits the implementation of institutional arrangements that is designed to facilitate the free flow of goods and services and coordinates foreign economic policies. Physical and geographical proximity is often seen as a reason for conflict among countries which can be drastically resolved by the formation of economic ties. Strong economic relation among BRICS countries reduces the chance of conflict, creating the possibility of a peaceful global atmosphere. The postliberalized international system has adopted new dimensions of regionalism and the concept of 'trade creating geography or space' is becoming prominent. This notion is based on the proposition that 'trade creates space', based on which the study evolves. The globalization, trade liberalization, transnationalism, and privatization prevailed to enhance the scope of this study on trade creates favorable space for BRICS. This paper analyses the evolving nature of BRICS in global political economy, in both political as well as economical aspects.
\end{abstract}

Key Words: BRICS, Economic Regionalism, Political Interdependences, and Economic Interdependences.

\section{Introduction}

In an era of regional integration and interdependence, organisation of countries like Brazil, Russia, India, China and South Africa (BRICS) can play a meaningful role in international level as well as regional in years to come. The theoretical contributions of Earnst Haas (1975) and Jacob Viner (1950) were influential in deriving the research problem. Major studies in this area have been undertaken on the changing patterns of intra-regional as opposed to inter- regional trade to determine the rate of regionalization. The BRIC Association, which started in 2009, and became BRICS with the joining of South Africa in 2010, is taken as a case study to examine the variables. The BRICS is a platform aiming for both political (short-term) 
as well as economic (long-term) alliances within a multilateral system, which makes it suitable for explaining and observing this new dimension of economic regionalism. This novel outlook on regionalism has been adopted by various organizations such as the Trans Pacific Partnership (TPP), Asia Pacific Economic Cooperation (APEC), and Regional Comprehensive Economic Partnership (RCEP). The current global setting validates that trade relations have an upper hand in maintaining convivial relations when compared to geographical and physical similarities.

The trade volume depicts the level of integration happening within BRICS. The concept of economic regionalism emphasizes in the creation of a peaceful global atmosphere through economic relations among the BRICS countries. It reduces tension among the countries through by forming economic interdependence. It can be viewed as a conscious attempt to manage the opportunities and constrains created by the dramatic increase in international economic ties since the end of World War II and Cold War. According to Maddison (1995), "trade expansion accompanies periods of sustained world economic growth (such as in the post- Second World War period) and that periods of depression are accompanied by the stagnation or contraction of world trade. In recent decades, the volume of world trade expansion has typically been two or three times as greater as growth in real income and income growth has been high compared to historical standards". Studies by Dollar (1992), Sachs and Warner (1995), Asian Development Bank (1997), and Edwards (1998) have supported the proposition that "openness promotes growth."Berg and Krueger (2003) observed "there has been no economy that has sustained fast growth without undertaking a significant degree of trade liberalization".

Joseph Nye argued that integration could be studied in multi-dimensional terms. In general, regionalism could be defined as preferential cooperation among nations that are relocated in terms of geographical proximity, with certain common characteristics such as historical, cultural, political, and so forth. The objective of cooperation might be economic, political, or cultural in nature (Nye, 1968). In this context the economic regionalism is considered more autonomous, outward-oriented, comprehensive and multi-dimensional process which included trade and economic integration, environment, social policy issues relating to security and democracy, where the nation states and other actors played an important role. The economic regionalism firstly promoted the necessary structural and economic reforms at national level, and secondly encouraged development at multilateral level. The economic regionalism, especially bilateral (between only two nations) and bi-regional (between a Regional Trading Agreement (RTA) and another country or group of countries) agreements, did not tend to form trade blocks as they were usually trans-regional in nature and intended to 

diversify trade relations among the large number of countries (Baldwin, 1993; Lombaerde and Garay, 2006; Ranjanet al., 2007; Lama, 2005; Spindler, 2002). According to Philippe De Lombaerde and Luk Van Langenhove, in 2005, "regional integration is a worldwide phenomenon of territorial systems that increase the interactions between their components and create new forms of organisation, co-existing with traditional forms of state-led organisation at the national level".

The recent summit, (2016) of the BRICS reiterates that more cooperation is needed at various level The BRICS focused on more representative international financial architecture demanding an increase in the voice and representation of developing countries and the establishment improved international monetary as well as trade systems that can serve the interests of all countries and support developing countries. Moreover, these economies are experiencing large scale growth and are now significant contributors to the global economy. One must acknowledge the fact that the BRICS countries are composed of various political systems in various subcontinents, but in a changed context, came together under the category of 'developing countries' in broader terms ( Jayan, 23, January, 2013).

The BRICS is a group which promotes the interest of the global South within a multilateral system. It constitutes of different political system which are authoritarian, totalitarian, democratic and federal characters. This consensus gives them the ability to influence global decision making and safeguard developing countries interests and concerns. The BRICS has projected itself as an independent group in a fast changing world. The BRICS is a relatively new group and its institutional structure is still evolving. A number of cooperation mechanisms have been developed, including the Action Plan and meetings of foreign, finance and trade minsters as well as central banks governors are taking place on a yearly basis to further enhance the working of this institution.

The BRICS economies have grown quite resilient to global shocks due to flexibility of their markets and economic policy frame works. Through increased trade and investment linkages, the BRICS countries are also increasingly growth drivers of low income countries (IMF report, 2011). The rich flow of FDI within this group, trade flows, and migration flows have substantiated their economic growth and development. These factors are considered to be evolving growth factors of their economic growth and development.

The BRICS does not represent a region (against a well known gravity model) ${ }^{1}$. Moreover mutual concerns and interest forms the core of this group in which regionalism is 
promoted through economic integration and interdependence among member states. The BRICS is usually referred to as a 'Three trillion dollar trade' club. In fact the total trade of BRICS is recorded as 3.41 Trillion USD, although it may be a convincing argument to consider the BRICS as a major trading bloc in international trade (IMF report, 2011). Thus trade is one of the integral factors uniting BRICS countries as a group.

\section{BRICS and Economic Growth}

The BRICS grouping is a new emerging group within international political economy which has the power to resist the Western hegemony in global level. The post financial crisis onwards BRICS economies are gaining power because of strong financial and centralized banking system to protect them from financial hurdles. This reality is emphasized to increase economic growth in their region.

The BRICS grouping is not a natural, historical, cultural, political or linguistic coalition. It is entirely an economic group, first popularized in an economic paper from Goldman Sach. In retrospect, the choice of Brazil, Russia, India, China and South Africa is nothing but 'a focuses on the emerging markets with largest GDP (in terms of PPP), and on their out big populations becoming more productive. Indeed, the father of the concept, Goldman Sach's Jim 'O' Neill writes in the growth map (2011), his latest reflection on the origin and evolution of BRIC (later South Africa joined), that the two most important determinates of GDP are demographics, and productivity. In terms of demography 'more working people make an economy easier to grow, unless of course they are extremely unproductive. More people produce more output; more people earn wages and income, ${ }^{2}$ which is basis for their consumption. As for productivity, the more a group of workers can produce with given set of outputs, from time to materials, the faster their economy will grew. In the year 2000, the GDP, in terms of PPP (see figure1) of US was at 22 percent in the world while GDP was slightly larger than 21.4 percent of combined BRICs.

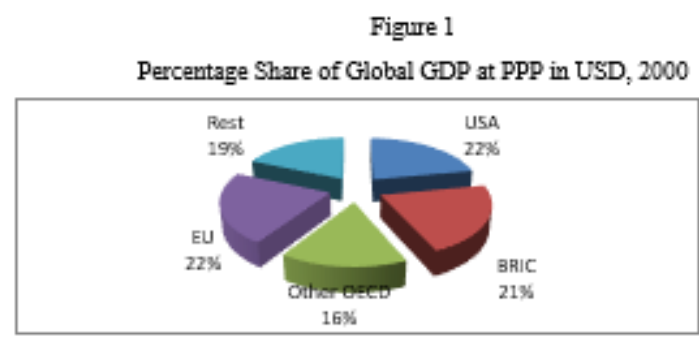

Source: IMF, World Economic Outlook, May $2001^{3}$ 
Eighteen years later, the combined GDP of BRICS was (see figure 2) 18.557Trillion USD, or 33 percent of world GDP, larger than US contribution of 20 percent. These changes in the BRICS contribution to world GDP was accomplished by consistently high growth rates in the BRICS, particularly in China and, to a lesser extent India. This dramatic change is the evidence that BRICS countries have influenced international economic growth which over take EU, and USA. In this context financial crisis made apparent change in BRICS economies for less effective rather than the EU and USA. This was the one of the reason BRICS is one of the largest credential factor of global economy.

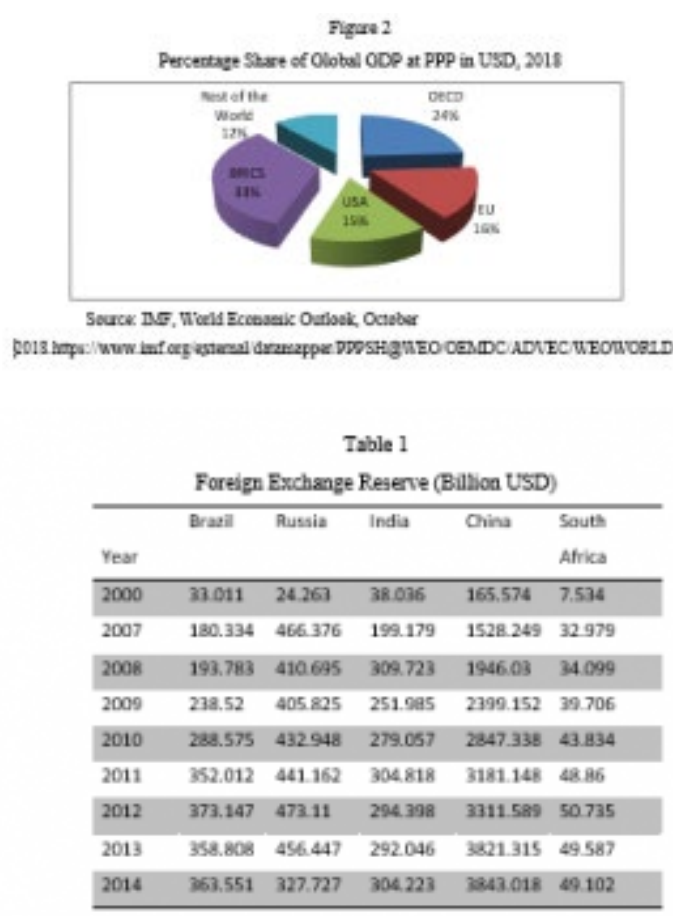

The above (table1) discusses on the matter of foreign currency reserves, BRICS's foreign currency reserves was enlarged from 268.4 Billion USD to 6793.81 Billion USD in 2000 and 2016. These foreign currency reserves are the main back borne their economy which maintained financial and macroeconomic stability. China's economic power also seems to ground in the scale of its foreign currency reserves. At 45.78 Billion USD, Chinese reserves, Brazil 360.17 Billion USD, India's 3010.57 Billion USD and even Russia's 3330.36 Billion USD, and South Africa's 47.35 Billion USD in 2016. The importance of this factor is illustrated by the wide spread expectations in October 2011 of a Chinese contribution to Euro zone bailout fund. Another way to see the dominance of India within the BRICS is to observe the exponential growth trajectory of the Indian economy with a relative slower pace of the other BRICS economy, especially China, Brazil and Russia in 2016. 


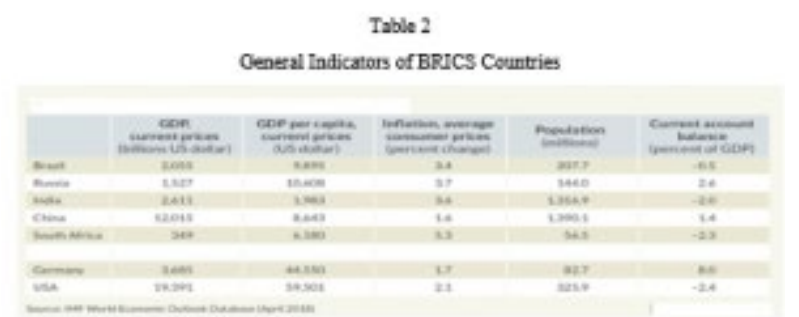

In the above table 2 will gave clear cut picture of BRICS total GDP estimated 18.557 Trillion USD in 2018. China is contributing highest (12 Trillion USD) in this group followed by India, Brazil, Russia, and South Africa respectively. In the case of Inflation average South Africa is highest in this group, followed by Russia, India, Brazil, and China. In the case of population growth, India and China marked 1.31 and 1.39 USD Billion population growth respectively. While China is the only member making current account surplus and remaining members contributed current account deficit in this group.

\section{BRICS and Multilateral Merchandise Trade System}

The BRICS have a prominent role in multilateral trade system especially in merchandise trade. The BRICS functions as a good exports destination and provides market access for all economies connected to multilateral trade system. In accordance with other regional organizations like EU, ASEAN, and NAFTA, BRICS have evolving nature in international trade. The comparisons with other regional organizations help to understand BRICS's influences in global trade.

The exports share of contributions with regard to merchandise world exports and data from four major regional groups are included for a comparative analysis. During the period 2001-08 European Union's share of contribution reached from 38 to 37 percent in world exports. The BRICS share of contribution increased in double from 7 to 15 percent in world exports. This tendency paved a growth path of BRICS economies towards future development and to overcome hurdles of the financial crisis. In the case of ASEAN, it maintained stable share contributions (6 percent) in world exports. The NAFTA is the only regional group that showed a declining share of contribution (from 18 to 8 percent) in world exports. The rest of the world share was almost stable contributing to 29 percent of world exports. In the period, 2009-17, The European Union's share of contribution declined periodically from 38 to 34 percent. The BRICS contribution eventually increased from 16 to 19 percent in world exports. ASEAN showed stable performance, and NAFTA showed a declining tendency during this 
period. While evaluating the overall performance of BRICS group, it has been observed that they performed well even in a constrained global trade environment while the global crisis had much impact on NAFTA, EU, and ASEAN countries. Share from the rest of world decreased from 29 to 26 percent in world exports.

The imports share contribution of world imports from regional organisations like EU, ASEAN, NAFTA, and BRICS. From 2001 to 2008, The EU's contribution significantly enlarged from 37 to 38 percent of world imports. Trade from rest of the world increased from 24 to 27 percent of world imports. In the case of BRICS and NAFTA, not much difference was made as they showed a decreasing tendency from 25 to 17 percent (NAFTA) of world imports. But in the case of BRICS, it touched from 6 to 12 percent of world imports contribution. The ASEAN share is more stable 6 percent of global trade, which shows that it has a stable influence on global trade. The period of 2009-17 witnessed EU's decreasing tendency from 37 to 33 percent of world imports contribution. The global financial crisis and Euro-zone crisis were major obstacles for their growth parameters which negatively affected their contribution in world imports. Trade among rest of the world remained stable at 26 percent, and BRICS maintained 16 percent of imports share in global trade. The NAFTA and ASEAN share of contribution was 18 and 6 percent respectively on world imports.

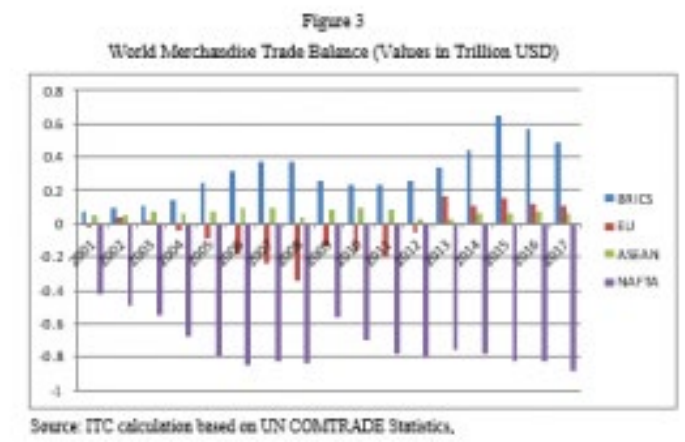

In the figure 3 gives a graphical representation of world trade balance with regard to merchandise trade. The rest of the world, EU, ASEAN, and BRICS enjoyed the camp of trade surplus whereas others fell into the deficit camp. The BRICS increased its surplus from 0.3 to 0.5 Trillion USD (2001-17). His is where we can see BRICS planned economic activities influencing more on their trade surpluses along with the BRICS intra-regional trade which reduced the trade deficits. The biggest importer and exporter of world trade, the EU faced trade deficits in the last consecutive years. In case of rest of world, it marked trade surpluses from - 


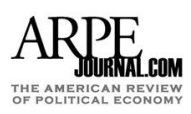

1 to 0.1 Trillion USD. This data details on the picture of flowing tendency of exports from lower developed countries to developed countries. In this context South -North trade relations are more significant in world trade. It was also found that northern countries more depended Southern countries cheaper products.

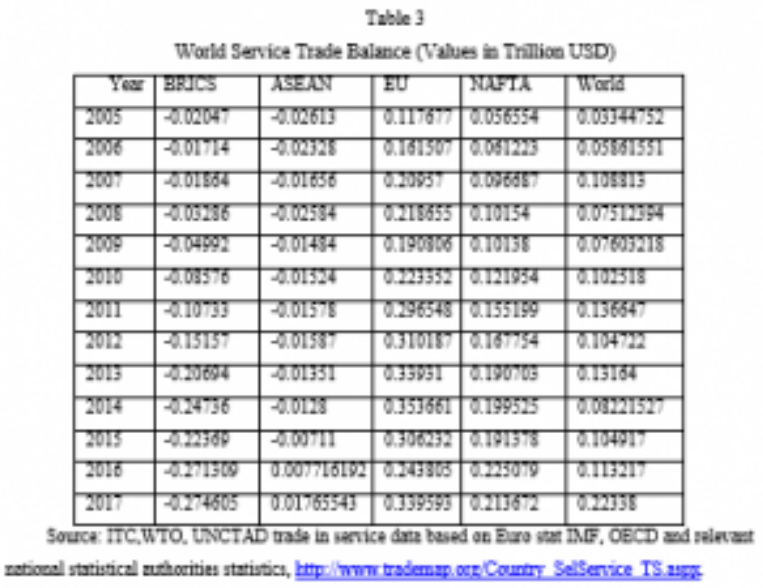

In the above table 3, illustrates the global service trade balance in aggregate level. From the period of 2005 to 2010, global service trade trend has been increasing steadily. In the case of EU, which dominates world service trade balance, an increase from 0.11 to 0.22 Trillion USD is shown during this period. The position covered by NAFTA show steady and increasing tendency from 0.05 to 0.12 Trillion USD of world trade. The BRICS in the initial stage of its institution building, but contribution share decreased from -0.02 to -0.08 Trillion USD in world trade balance. ASEAN's share of contribution is maintained more or less stable at the level of -0.02 Trillion USD.

Data from the period of 2011-17 shows that the EU (0.33), NAFTA (0.21), BRICS (0.27 ), and ASEAN (0.01) had their share of contribution in service trade balance respectively. This data supports the proposition that global financial crisis had a minimal impact on world service trade balance. The EU and NAFTA groups share a dominant position in world service trade and have been sharing an upward trend. But the BRICS and ASEAN are in hurdles and have been showing down ward tendencies in global trade due to lowest demand of their service products in world markets. So that BRICS and ASEAN in the sea shore of trade deficit and rest of the remaining like the EU and NAFTA are the well advance position of trade surpluses in global service trade. 


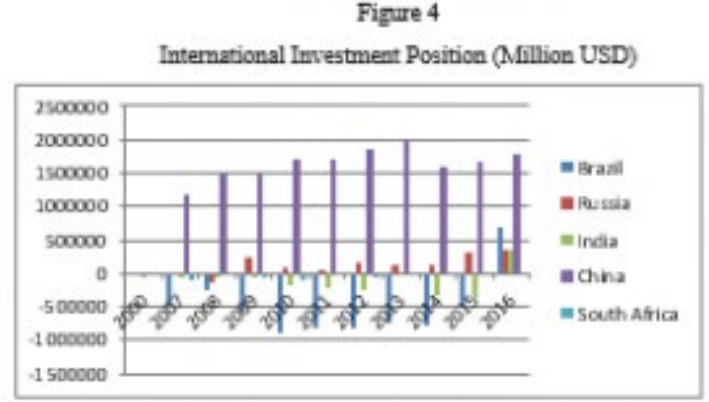

Source: BRICS Joint Steristical Report 2017.

The above figure (4) shows that South Africa and China are the investment jargon among the BRICS group. India, Brazil, and Russia are major recipients from rest of the world. India, Brazil and South Africa have deficiencies in infrastructural development, so that they are major recipients of global investment. Russian and Chinese multinational companies invested all over the world especially in the continents of Africa, Latin America, Asia and Middle East. This is one of the reasons behind their increasing investment position globally.

\begin{tabular}{llllll}
\multicolumn{5}{c}{ Table 4 } \\
\hline \multicolumn{5}{c}{ Inflows of FDI (Million USD) } \\
\hline 2000 & 32,995 & $\ldots .$. & 4031 & 40715 & 888 \\
\hline 2007 & 44579 & 55874 & 34844 & 74768 & 6530 \\
\hline 2008 & 50,716 & 74783 & 41903 & 92395 & 9220 \\
\hline 2009 & 31,481 & 36583 & 37746 & 90033 & 7535 \\
\hline 2010 & 88,452 & 43168 & 36047 & 105735 & 3635 \\
\hline 2011 & $1,01,158$ & 55084 & 46552 & 116011 & 4248 \\
\hline 2012 & 85,607 & 50588 & 34298 & 111716 & 4559 \\
\hline 2013 & 69,181 & 69219 & 36047 & 117586 & 8304 \\
\hline 2014 & 96,895 & 22031 & 45147 & 119562 & 5775 \\
\hline 2015 & 74,694 & 6853 & 55559 & 126267 & 1730 \\
\hline 2016 & 78,182 & 32976 & $\ldots .$. & 126001 & 2271 \\
\hline
\end{tabular}

The above table (4) shows China as the leading country among the BRICS with regard to FDI inflow. Second position is held by Brazil, then India, Russia and followed by South Africa. In this context China actively plays the role of an investor in supporting the interests of the BRICS along with the support of developing countries interests. China can at this point effectively use BRICS as a platform to resist Western countries interest and hegemony, because of which China invested more into BRICS. BRICS nations received a total of 294.98 Billion USD FDI inflows into their group in 2016. It shows the increasing economic interdependence among the BRICS countries, which boosted their economic growth and development. 


\begin{tabular}{|c|c|c|c|c|c|}
\hline \multicolumn{6}{|c|}{ Outflows of FDI (Million USD) } \\
\hline & Brazil & Russia & India & China & South Africa \\
\hline 2000 & 2497 & $\ldots$. & 759 & $\ldots$. & -759 \\
\hline 2007 & 17061 & 44901 & 18835 & 26506 & -2962 \\
\hline 2008 & 26115 & 55663 & 19365 & 55907 & 3137 \\
\hline 2009 & -4552 & 43281 & 15143 & 56529 & -1156 \\
\hline 2010 & 26763 & 52616 & 17195 & 68811 & 76 \\
\hline 2011 & 16067 & 66851 & 10892 & 74654 & 257 \\
\hline 2012 & 5208 & 48822 & 7134 & 87804 & -2988 \\
\hline 2013 & 14942 & 86507 & 9199 & 107844 & -6652 \\
\hline 2014 & 26040 & 57082 & 4031 & 123120 & -7675 \\
\hline 2015 & 13518 & 22805 & 8896 & 145667 & -5747 \\
\hline 2016 & 7815 & 22581 & - & $\ldots$. & -3382 \\
\hline
\end{tabular}

The above table (5) shows that China is the leading state among the BRICS with regards to FDI outflow. Second position held by Russia, then India, Brazil and followed by South Africa. In this context India and China compete on the African markets on the basis of FDI outflows. Brazil has tremendous of foreign currency reserves which have influenced their Foreign Development Investment (FDI) abroad. China and India actively played a pivotal role in Africa and its infrastructural development, resulting in total BRICS FDI out flow of 181.56 Billion USD in 2016. This was one of the major evidence of their active involvement in global affairs for promoting developing countries interests and concerns. To conclude with, we can see that the above data shows a greater evidence for BRICS economic growth through FDI and trade. The similarities within BRICS economies play a significant role in their growth such as like rich contribution of labour and materials resources, educated youths, developed financial and banking system and macroeconomic stabilities have influenced their economic growth. Within all this, trade is considered as an integral part in strengthening their relationship.

As the BRICS countries increasingly integrated their national economies into the global economic system, their economic wealth started to grow, due to cheap labour costs, and their relatively well educated middle class that thrived in the new information economy. For most of the BRICS, this resulted in rapid industrialization as market economic dynamics shifted manufacturing to location where goods were cheaper to produce. ${ }^{3}$

The BRICS thrived because of their natural resources, high education level and its countries becoming gateways into their regions. The countries, in order to attract more Foreign Direct Investment, started to transform their domestic economic structures to capitalize from export led growth. It is thus somewhat ironic that whilst their rapid growth and growing economic influence is derived from the degree to which they become more integrated into the 


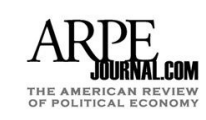

global free market economy; their political power is symbolized by the degree to which they are able to suggest an alternative to the current global order.

Most of the analysis reflects the argument that while many emerging powers may be dissatisfied with significant characteristics of current world order, they do not offer a clear alternative to existing global order. As consequence we are not witnessing the demise of United States great power status, but the emergence of chaotic world order with numerous rising powers and with unclear principles and drivers of the world order. The political emergence of the BRICS group in the international system will lead to a dynamic reform in international economic order as well. This prominence in international political economy is what the BRICS members seek to achieve as a group.

The technological development has helped these countries to become closer as a group with concerns and interests refluxed as binding factors. The level of integration is decided by trade among the group. The excellent military-technological complex, socio-economic stability and fast growing economies of member countries creates a sustainable condition for the group to assert its position in international economy. The Common Wealth Independent states (Eastern European and Central Asian states), COMESA (East and Southern African states), APEC (Asian and Pacific states) and RECP are the present champions of open regionalism apart from the BRICS. They have been formulated on the basis of trade relations and not on geographical proximity. Hence trade relations can be seen to create favourable places of integration among states which upholds the essence of open regionalism and supports the notion that 'trade creates geography'.

\section{BRICS's Engagement in Global Environment}

The first meeting of the BRICS grouping place between leaders from Brazil, Russia, India and China, in Yekaterinburg, Russia on 16 June 2009. At the first meeting the BRIC countries discussed the situation of the global economy and other pressing issues of global development, and also prospects for further strengthening the BRIC group.

The first meeting took place in the context of emerging global financial crisis, and in the first summit communiqué released after the summit the BRIC leaders stressed the central role played by the G20 summits in dealing with financial crisis. In so doing they emphasized that financial crisis had brought about a recognition that global economy could no longer be managed by the $\mathrm{G}^{4}$ alone, but that a wider grouping of states, including the BRIC countries 
was now critical to co-managing the global economy, and especially the global financial system.

The third summit took place in Sanya, China on 14 April 2011, and at this meeting the Republic of South Africa joined this group and it was renamed the BRICS group. The fourth summit of the BRICS countries took place in the capital of India, New Delhi; on 29 March 2012. The above summits are giving clear cut picture of BRICS protecting and promoting developing countries concerns and interests.

Moreover this reflected a gradual shift in the focus of the BRICS, away from its origin as an aspiring group that had in common an alternative vision for the future, to a group that was more present in current international affairs, and that actively cooperated to pursue common interests in a broad range of international forums in multilateral system.

The fifth summit of BRICS leaders was held in Durban, South Africa, on 27 March, 2013. The summit communiqué stated that the discussion at the fifth summit reflected the growing intra BRICS solidarity as well as its shared goal to contribute positively to global peace, stability, development and cooperation. Moreover the summit communiqué also stated the BRICS aim to develop itself progressively into a fully-fledged mechanism of current and long term coordination on wide range key issues of the world economy and politics.

The last summit $\left(8^{\text {th }}\right)$ held at Goa, they strongly condemn several terrorist attacks, against some BRICS countries, including that in India. They strongly condemned on terrorism in all its forms and manifestations and stressed that there can be no justification whatsoever for any acts of terrorism, whether based upon ideological, religious, political, racial, ethnic or any other reasons. They agreed to strengthen cooperation in combating international terrorism both at the bilateral level and at international forums ${ }^{5}$ ( $8^{\text {th }}$ BRICS Summit Reports, 2016, p. 12). To address the threat of chemical and biological terrorism, they supported and emphasised the need for launching multilateral negotiations on an international convention for the suppression of acts of chemical and biological terrorism, including at the Conference on Disarmament. In this context, they welcomed India's offer to host a Conference in 2018 aimed at strengthening international resolve in facing the challenge of the WMD-Terrorism nexus. ${ }^{6}$ This will emancipate BRICS role in counter terrorism, which aimed to seek demoralizing terrorist activities in global level. They acknowledged the recent meeting of the BRICS High Representatives on National Security and, in this context, welcomed the setting up and 


\section{ARPEE}

American Review of Political Economy

June 28,2020

organising the first meeting of the BRICS Joint Working Group on Counter-Terrorism on 14 September 2016 in New Delhi.

The conclude that the communiqués released after first eight summits of the BRICS countries articulate an alternative vision for a new global order that is more democratic, just, fair, rule based, and which requires the collective decision making and co-management of all states, both when it comes to the specifics of international financial system and its institutions, but also more broadly as it pertains to international trade and the political system, including global institutions like the UN.

With concepts like democracy, fairness and rule governed behaviour, the BRICS countries are signalling that they perceive that current global order to be undemocratic, unjust and arbitrarily manipulated by a dominant super power supported by an alliance of developed countries in the North. The BRICS hold that the existing global governance architecture is regulated by institutions that were developed to deal with a very different set of challenges and opportunities. As the global economy is being reshaped, the BRICS should explore new models and approaches to global governance which strives for more equitable development and inclusive growth. ${ }^{7}$

\section{Major Challenges of BRICS}

The BRICS itself identified the major challenges to be bilateral trade issues, environmental degradation and climate change, intellectual property issues, discrimination nature of IMF quota reforms, nuclear issues etc. The BRICS maintained developing countries interests and concerns of above mentioned challenges which nurture the wider prospects of BRICS in global level. Bilateral trade issues form an important source of concern among the BRICS countries, which illustrated the main setback of their relations. The major Summits held have discussed on reducing bilateral trade issues among this group, which makes this a fine platform for expressing their concerns and prospects. The lack of strong institutional architecture has had adverse effects on the BRICS platform and it should be overcome by highest level diplomatic tie-ups and leader's meet among the BRICS community.

Another major challenge on the BRICS countries' economies is the drastic change in national policies of these countries. The swap currency arrangement (Contingent Reserve Arrangements) on trade transaction will help in resolving technical challenges faced by these economies with regard of point level transaction on trade. The currency convertibility is 
another hurdle for their transaction which creates large setback in their financial and currency exchange cooperation.

Moreover, geopolitical interests of each member nations are also a major challenge within the group. For the time being, China - India relations are affected by Pakistan with Chinese interest on Pakistan as geopolitical strategic location adversely affects India's interests in South Asia. The recent initiative like Chinese One Belt One Road, the CPEC (ChinaPakistan Economic Corridor) negatively targets on Indian interests on Arabian ocean. Similarly China is suspicious on India's geopolitical interests on South China Sea which creates mutual distrust and tension in their bilateral relation. In the same way Russia -China's relations, both countries geopolitical interests on oil will be decided on their synergies and cooperation. The other two members (Brazil and South Africa) are geographically at a distance from India. These countries are situated in different continents, Latin America and Africa. This is a positive aspect for BRICS as they are less in conflict with the other partners like China, India, and Russia. This logical narrative illustration states that a group of countries identical geographical location creates more conflicts and tension rather than those from non-geographical relations.

The BRICS itself identified the major challenges to be bilateral trade issues, environmental degradation and climate change, intellectual property issues, discrimination nature of IMF quota reforms, nuclear issues etc. The BRICS maintained developing countries interests and concerns of above mentioned challenges which nurture the wider prospects of BRICS in global level. Bilateral trade issues form an important source of concern among the BRICS countries, which illustrated the main setback of their relations. The major Summits held have discussed on reducing bilateral trade issues among this group, which makes this a fine platform for expressing their concerns and prospects. The lack of strong institutional architecture has had adverse effects on the BRICS platform and it should be overcome by highest level diplomatic tie-ups and leader's meet among the BRICS community.

Another major challenge on the BRICS countries' economies is the drastic change in national policies of these countries. The swap currency arrangement (Contingent Reserve Arrangements) on trade transaction will help in resolving technical challenges faced by these economies with regard of point level transaction on trade. The currency convertibility is another hurdle for their transaction which creates large setback in their financial and currency exchange cooperation.

\section{Conclusion}


To conclude that the economic growth of BRICS is unquestionably the stepping stone to its development, which is going to benefit around 43 percent of world population dwelling in the five member countries. One of the major objectives of the group is the development of a multilateral system which supports developing countries interests and concern in global level. It can be seen that regarding certain issues, the BRICS act as coalition block within a multilateral system on issues related to IPR, antidumping, environment, food subsidies and IMF quota reform. Another important power orientation of BRICS is that the memberships of countries like Russia and China had veto power (permanent members) and rest of the countries as non-permanent members in the United Nation Security Council, having a say on global security issues. This is the one of the aspect BRICS should promote shared democratic values in multilaterals institutions. Moreover the BRICS nations are members of major international institution like WTO, IMF, World Bank, G20, and UN which also influences the group on having the power to determine and negotiate on matters of international importance. The continental accessibility of countries such as like in Latin America, Africa, South Asia, Asia, and Eurasia enhances the increases the role BRICS's in a global trade system and global politics. Moreover the authoritarian, totalitarian, democratic and federal interests working towards common concerns and interest makes it a unique group. In this context BRICS's intraregional trade relations have made it possible to achieve trust and cooperation among the member states especially through the promotion of economic interdependence. As well defined institutional mechanism needs to build in order to better evaluate and manage strong economic ties among the member states.

The Contingent Reserve Arrangement (CRA) is another millstone initiative from BRICS summit which emphasized financial stability among the member states. Under this initiative trade transaction is calculated through their own currencies, for example India can import from BRICS countries using Indian currency which makes appreciation tendency of Indian currency. Moreover India can import largely manufacturing products from China using Indian currency which satisfy our large domestic demand. Same way India can largely import crude oil from Russia to satisfy our domestic consumption through medium of Indian currency. In other way India can import Brazilian minerals and metals to reduce raw material scarcity in our industrial sector using Indian currency. The same way India can largely import South African gold for maintaining financial stability using Indian currency. The CRA helps BRICS member states to reduce the use of US dollar in their trade transaction, which is good for their economy to reduce financial and macroeconomic instability. The CRA is a positive influential 
factor in BRICS intra-regional trade. It is these facts that make the CRA an integral part of regional integration in BRICS group which promote economic regionalism. This is a new dimension of regional integration in international political economy which does not emphasise geographical proximity. The BRICS is on an on-going process of new dimension of regional integration, becoming possible through mutual interests and concerns. The BRICS intraregional trade facilitates the member countries national interests into mutual interest. These factors play a vital role in BRICS regional integration process in the backdrop of the concept of economic regionalism. Moreover CRA becomes an important trade creation factor of BRICS regarding intra-regional trade, which results in member states becoming further economically interdependent.

The next major initiative from BRICS is an export credit arrangement which gives a favourable platform for trade to take place. For a country like India with balance of payments not favourable, this initiative greatly benefits exports growth and reduces the burden of trade deficit. The world trade depends on dollar terms trade, so that we can access anything from BRICS through credit bases. It is also an influential factor in India's foreign trade with regard to BRICS. This may favourer in the initiation of trade relations for BRICS member like Brazil, South Africa, and India along with Russia and China. This initiative will facilitate by reducing the trade gap between India and China, Brazil and China, South Africa and China, India and Russia, Brazil and Russia, and South Africa and Russia.

The geographical and political supremacy of the constituent countries in their own region should be used to further assert the role of BRICS, thereby giving it a strong voice in global politics. The BRICS Summits could be effectively used as a platform to promote bilateral discussions among other regional or non-regional groupings to which the constituent countries are part of. The new trend which can be noticed in the last few BRICS summits is the inclusion of neighbouring states of the member countries as partial stakeholders. These relations are visible in various summits held on Fortaleza (Mercosur countries), Durban (African countries), Goa (South Asian countries), and Ufa (Shanghai Cooperation members). This will further enhance the possibility of cooperation through bilateral and multilateral engagements and can be used to reinstate the BRICS identity in a complex and highly interdependent global arena. The BRICS association will become more transparent and division of powers within the institution will be ensured with by constituent bodies such as like New Development Bank, Contingent Reserve Arrangements, Business Forum, and Trade Union. It will help foster greater intra-regional trade among BRICS countries and in the setting 
up of a strong institutional architecture. This will help BRICS to solve and effectively negotiate political tensions among member states, thereby giving it legitimacy and a strong voice in a multilateral world order.

The BRICS's evolution on multilateral trade system is that it protects developing countries interests in multilateral forums like UN, IMF, WTO and G20 summits. The BRICS act as a bargaining coalition bloc for various causes like IPR, environmental issues, antidumping issues, labour standardization, and tariff issues. It aims at protecting developing countries interests and concerns against Western dominations in above mentioned multilateral forums. The countries like India and Brazil alone can't influence multilateral forums for which this organisation gives them a reasonable negotiating space in a multilateral system. So that major international institutions are like IMF, WTO is compelled to admit BRICS suggestions in their negations. The BRICS nations act as a bargaining coalition bloc in IMF meetings with regard of quota reforms. The next example is in the matter of Intellectual Property Rights issue (IPR), the BRICS nations considers it as a common issue which generated developing countries interests and concerns in IPR issues. At the first meeting itself, the BRIC countries discussed the situation of the global economy and other pressing issues of global development, and strengthening collaboration within the BRIC group. This results in BRICS synergies and complements with each other in terms of their economic cooperation. The concludes of the various communiqués released after first five summits of the BRICS countries articulate an alternative vision for a new global order that is more democratic, just, fair, rule based, and which requires the collective decision making and co-management of all states, both when it comes to the specifics of international financial system and its institutions, but also more broadly as it pertains to international trade and the political system, including global institutions like the UN. The macroeconomic, financial, energy, climate change and development policies of the BRICs countries as reflected in the outcomes of the ten summits held between 2009 and 2018 clearly reflect a strategy aimed at bringing about a world order that will reflect a new political economy that is no longer central around serving the interests of the Western developed world, but instead seeks to find a balance between North and South in global politics. The vision of BRICS for economic, financial and development dimensions of a new global order are thus closely aligned with their vision for the political dimension. In this context BRICS summits and released communiqués are referred as integral part of their integration not in terms of economic dimension but in terms of political dimension. While considering the overall economic dimension of BRICS, its economic growth that is the stepping stone of its 
development. It gives the organisation a power over multilateral power which supported developing countries interests and concern in global level.

Another evolution factor is that the BRICS Business council coordinates multinational companies from BRICS countries for the adherence of deep integration among the group. Countries like India, Brazil and South Africa might give a good platform for receiving strong investment from China and Russia. The linkages between multinational companies and BRICS countries help in reducing tension and fostering deep cooperation among them.

The country like India, BRICS initiatives help in resolving bilateral issues with China in terms of border conflicts. The Chinese initiatives like One Belt One Road (OBOR) programme helps to resolve border conflict with India and supports India -China economic relationship. China is willing to start student exchange programmes with India which will take the sophisticated Sino-Indian relationship to a new dimension. The Sino-Indian relationship should be viewed more in economic rather than military and social terms. Here economic relationship becoming mutually benefiting for each other reduces conflict and finally leads to synergetic cooperation with two rich civilization. To over all conclude, BRICS nations less geographical proximity help in its integration process for making strong economic ties. The new dimension of regionalism prevail through trade create space on BRICS nations. The countries are home to 42 per cent of the world's population. Their total share in the global economy has risen from 12 per cent to 23 per cent in the past decade, while contributing more than half of global growth with strong international voice on power politics which made a good path way of BRICS's evolution on international political economy.

\section{REFERENCES}

Beausang, Francesca. (2012). Globalization and the BRICs. Palgrave Macmillan publications.

Coning, de Cederic. Mandrup, Thomas. and Odgaard, Liselotte. (ed.). (2014). The BRICS and Coexistence : An Alternative Vision of World Order. Rutledge Publications. pp. 27-44.

D, Wilson. and A, Stupnytska (28, March, 2007). The N-11: More than an Acronym. London: Goldman Sachs Global Economic paper. Vol. No.153. Goldman Sachs\& Co.

Jayan, P.A. (23, January, 2013). BRICS: Advancing Cooperation and Strengthening Regionalism. India Quarterly: Journal of International Affairs.

M, Ariff. and A, Khalid. (2000). Liberalization, growth and the Asian Financial Crisis: Lesson for Developing and Transitional Economies in Asia. UK: Chelthenham. Edward Elgar Publication. 
Mathur, Sajal. and Gupta, Das. Meghna.(2013). BRICS Trade Policies, Institutions and Areas of Deepening Cooperation. New Delhi: Centre for WTO Studies. IIFT.pp.7-12.

Saran, Samir.and Singh, Kumar. Ashok. (ed.). (2013). A Long-Term Vision for BRICS. Submission to the BRICS Academic Forum. New Delhi: Observer Research Foundation. pp. 3-6.

Wallesrtein, Immanuel. (2007). World Systems Analysis: An Introduction. Durham. Conn. Duke University Press.

End Notes

${ }^{1}$ The gravity model of international trade in international economics, similar to other gravity models in social science, predicts bilateral trade flows based on the economic sizes (often using GDP measurements) and distance between two units.

${ }^{2}$ www.springer.com

${ }^{3}$ De Coning, Mandrup, and Odgaard. op.cit.

${ }^{4} \mathrm{G} 8$ became G7 in March 2014 when Russia was excluded due to its annexation of Crimea.

${ }^{5}$ www.netindian.in

${ }^{6} 8^{\text {th }}$ BRICS Summit reports. op. cit.

${ }^{7}$ Ibid., 